\title{
ANALISIS BERWUJUD (TANGIBLE), KEHANDALAN (RELIABILITY), KETANGGAPAN (RESPONSIBILITY), JAMINAN (ASSURANCE) DAN EMPATI (EMPATHY) (PELAYANAN SATU PINTU) TERHADAP KEPUASAN MASYARAKAT PADA POLRES HULU SUNGAI TENGAH (HST) KALIMANTAN SELATAN
}

\author{
Noor Ifansyah \\ Sekolah Tinggi Ilmu Ekonomi Pancasetia \\ Jl. Ahmad Yani Km. 5.5 Banjarmasin \\ ifansw4li85050858@gmail.com
}

\begin{abstract}
Abstrak : Noor Ifansyah, Npm. 1711.32202.4607, Analisis Berwujud, Kehandalan, Ketanggapan, Jaminan Dan Empati (Pelayanan Satu Pintu) Terhadap Kepuasan Masyarakat Pada Polres Hulu Sungai Tengah (Hst) Kalimantan Selatan, Dibawah Bimbingan Rosadiro Cahyono Dan Melania, 2020. Tujuan yang ingin dicapai dalam penelitian ini, adalah untuk mengetahui dan menganalisis pengaruh variabel berwujud terhadap kepuasan masyarakat, untuk mengetahui dan menganalisis pengaruh variabel kehandalan terhadap kepuasan masyarakat, untuk mengetahui dan menganalisis pengaruh variabel ketanggapan terhadap kepuasan masyarakat, untuk mengetahui dan menganalisis pengaruh variabel jaminan terhadap kepuasan masyarakat, untuk mengetahui dan menganalisis pengaruh variabel empati terhadap kepuasan masyarakat, untuk mengetahui dan menganalisis pengaruh variabel berwujud, kehandalan, ketanggapan, jaminan dan empati secara simultan terhadap kepuasan masyarakat. Teknik pengolahan data yang akan dilakukan menggunakan metode kuantitatif dan analisis data dilakukan berdasarkan data primer yang diperoleh langsung melalui penyebaran kuisioner dengan skala likert kepada responden yang selanjutnya akan dianalisis dengan analisis regresi. Populasi dalam penelitianadalah masyarakat dengan jumlah sampel ditentukan sebanyak 100 responden. Kata Kunci Berwujud, Kehandalan, Ketanggapan, Jaminan, Empati dan Kepuasan Masyarakat
\end{abstract}




\section{PENDAHULUAN}

\subsection{Latar Belakang Masalah}

Peraturan Menteri Aparatur Negara Dan Reformasi Birokrasi Republik Indonesia No. 14 Tahun 2017 tentang pelayanan, menjelaskan pelayanan bertujuan untuk memberikan kepastian, meningkatkan kualitas dan kinerja pelayanan sesuai dengan kebutuhan masyarakat dan selaras dengan kemampuan penyelenggara sehingga mendapatkan kepercayaan masyarakat. Standar pelayanan adalah tolak ukur yang dipergunakan sebagai pedoman penyelenggaraan pelayanan dan acuan penilaian kualitas pelayanan sebagai kewajiban dan janji penyelenggara kepada masyarakat dalam rangka pelayanan yang berkualitas, cepat, mudah, terjangkau dan terukur. Pelayanan akan mampu meningkatkan kepuasan masyarakat melalui usaha ditentukannya kualitas jasa yang di kehendaki sehingga jaminan kualitas menjadi prioritas utama dan dijadikan tolak ukur keunggulan instansi. Untuk memperoleh gambaran tentang kepuasan masyarakat, maka perlu diketahui arti kualitas pelayanan. Oleh sebab itulah apabila pihak instansi pemerintah maupun instansi lain mampu menerapkan standar kualitas layanan secara baik, maka akan dapat menciptakan kepuasan masyarakat. Kepuasan masyarakat dapat memberikan manfaat diantaranya hubungan antara instansi pemerintah dengan masyarakat menjadi baik, memberikan dasar yang baik dan terciptanya loyalitas masyarakat serta membentuk suatu rekomendasi dari mulut ke mulut yang menguntungkan bagi pihak organisasi/instansi ke depannya nanti. Dengan dasar itulah, maka menilai pelayanan melalui pengukuran tingkat kepuasan masyarakat terhadap jasa yang ditawarkan organisasi/instansi pemerintah perlu dilakukan agar sejauh mana tingkat kepuasan yang dirasakan oleh masyarakat dengan adanya pengukuran tingkat kepuasan masyarakat pihak instansi/organisasi pemerintah akan lebih mengetahui faktor pelayanan, seperti apa saja yang mempengaruhi kepuasan masyarakat. Pengukuran kepuasan merupakan elemen penting dalam proses evaluasi kinerja dimana tujuan akhir yang hendak dicapai adalah menyediakan pelayanan yang lebih baik, lebih efisien, dan lebih efektif berbasis dari kebutuhan masyarakat. Suatu pelayanan dinilai memuaskan bila pelayanan tersebut dapat memenuhi kebutuhan dan harapan pengguna layanan. Kepuasan masyarakat dapat juga dijadikan acuan bagi berhasil atau tidaknya pelaksanaan program yang dilaksanakan pada suatu lembaga layanan publik. Sejalan dengan hal tersebut Polres Hulu Sungai Tengah (HST) merupakan sebuah lembaga kepolisan yang aktivitasnya memelihara keamanan dan ketertiban masyarakat, menegakkan hukum serta memberikan perlindungan, pengayoman dan pelayanan kepada masyarakat serta melaksanakan tugas tugas Polri lainnya dalam daerah hukum Polres sesuai ketentuan peraturan dan Undang-undang. Kepolisian Negara Republik Indonesia menerangkan Undangundang No 2 Tahun 2002 menjelaskan tugas pokok Kepolisian Negara Republik Indonesia diantaranya adalah mengeluarkan surat izin dan/atau surat keterangan yang diperlukan dalam rangka pelayanan masyarakat, memberikan izin dan mengawasi kegiatan keramaian umum dan kegiatan masyarakat lainnya, menyelenggarakan registrasi dan identifikasi kendaraan bermotor dan memberikan surat izin mengemudi kendaraan bermotor. Polres Hulu Sungai Tengah (HST) Kalimantan Selatan selama ini berusaha memberikan pelayanan terbaik kepada masyarakat namun, dirasakan masih belum maksimal, dimana terlihat dari adanya tanggapan dari beberapa masyarakat yang merasa kurang puas dan nyaman dalam pelayanan yang diberikan oleh Polres Hulu Sungai Tengah (HST) Kalimantan Selatan, mereka mengganggap aktivitas kerja pemberian surat ijin atau surat keterangan (SKCK) maupun SIM dari pihak kepolisian sering lambat dan pihak polres belum mampu menghilangkan adanya pungutan serta 
percaloan dilain pihak terlihat pula fungsi pemberdayaan dan pembinaan bagi masyarkat aktivitasnya sangat minim. Selain itu dalam hal pelayanan lalu lintas terlihat fungsi Sabhara di Polres Hulu Sungai Tengah (HTS) Kalimantan Selatan terlihat belum maksimal, yan mana masih terlihat dibeberapa titik keramaian kerap kali pihak anggota polisi tidak ada bertugas dan pos jaga kosong. Melihat dari permasalahan yang ada serta data pelayanan yang diberikan selama ini terlihat aktivitas pelayanan pada Polres Hulu Sungai Tengah (HST) Kalimantan Selatan terkesan lambat dan tidak sesuai dengan harapan masyarakat serta belum sesuai dengan Peraturan Pemerintah Nomor 16 Tahun 2014 bab I pasal 1 maksudnya kegiatan pelayanan publik kepada masyarakat adalah kegiatan atau rangkaian kegiatan dalam rangka pemenuhan kebutuhan pelayanan sesuai dengan peraturan perundang-undangan bagi setiap warga negara dan penduduk atas barang dan jasa pelayanan administratif yang disediakan oleh penyelenggara pelayanan publik/masyarakat serta belum sesuai dengan tujuan pelayanan terpadu yang diselenggarakan oleh instansi pemerintah seperti bertujuan (1) memberikan perlindungan dan kepastian hukum pada masyarakat (2) mendekatkan pelayanan kepada masyarakat (3) memperpendek proses pelayanan (4) mewujudkan proses pelayanan yang cepat, mudah, murah, transparan, pasti, dan terjangkau (5) memberikan akses yang lebih luas kepada masyarakat untuk memperoleh pelayanan. Hasil wawancara penulis kepada masyarakat terkait dengan kualitas layanan yang diberikan oleh pada anggota kepolisian pada Polres Hulu Sungai Tengah (HST) Kalimantan Selatan dari 10 orang masyarakat, diketahui bahwa respon masyarkat sebanyak 3 orang menyatakan puas, 4 orang menyatakan kurang puas dan sebanyak 2 orang menyatakan sangat kurang puas dan 1 orang menyatakan tidak memberikan tanggapannya terhadap kualitas layanan pada Polres Hulu Sungai Tengah (HST) Kalimantan Selatan.
Melihat dari penjelasan dan hasil wawancara tersebut masih terdapat adanya ketidakpuasan masyarakat terhadap pelayanan yang diberikan oleh para anggota kepolisian Polres Hulu Sungai Tengah (HST) Kalimantan Selatan. Berdasarkan dari uraian tersebut, maka dalam penelitian ini mengembangkan tema dengan judul Analisis Berwujud (Tangible), Kehandalan (Reliability), Ketanggapan (Responsibility), Jaminan (Assurance) Dan Empati (Empathy) (Pelayanan Satu Pintu) Terhadap Kepuasan Masyarakat Pada Polres Hulu Sungai Tengah (HST) Kalimantan Selatan.

\subsection{Rumusan Masalah}

Menurut Zeithhaml, Parasuraman \& Berry (dalam Hardiansyah 2011:46) untuk mengetahui kualitas pelayanan yang dirasakan secara nyata oleh konsumen, ada indikator kualitas pelayanan yang terletak pada lima faktor kualitas pelayanan, yaitu berwujud (tangible), kehandalan (reliability), ketanggapan (responsibility), jaminan (assurance) dan empati (empathy). Sehubungan dengan latar belakang adapun yang menjadi perumusan masalah dalam penelitian ini sebagai berikut:

1. Apakah berwujud (tangible) berperngaruh signifikan terhadap kepuasan masyarakat pada Polres Hulu Sungai Tengah (HST) Kalimantan Selatan?

2. Apakah kehandalan (reliability) berpengaruh signifikan secara terhadap kepuasan masyarakat pada Polres Hulu Sungai Tengah (HST) Kalimantan Selatan?

3. Apakah ketanggapan (responsibility) berpengaruh signifikan terhadap kepuasan masyarakat pada Polres Hulu Sungai Tengah (HST) Kalimantan Selatan?

4. Apakah jaminan (assurance) berpengaruh signifikan terhadap kepuasan masyarakat pada Polres Hulu Sungai Tengah (HST) Kalimantan Selatan?

5. Apakah empati (empathy) berpengaruh signifikan terhadap kepuasan masyarakat pada Polres Hulu Sungai Tengah (HST) Kalimantan Selatan? 
6. Apakah berwujud (tangible), kehandalan (reliability), ketanggapan (responsibility), jaminan (assurance) dan empati (empathy) berpengaruh signifikan secara simultan terhadap kepuasan masyarakat pada Polres Hulu Sungai Tengah (HST) Kalimantan Selatan?

\section{TINJAUAN PUSTAKA}

\subsection{Landasan Teori}

\subsubsection{Layanan}

Pelayanan yang baik memungkinkan sebuah perusahaan memperkuat kesetiaan pelanggan dan meningkatkan pangsa pasar (market share), karena itu pelayanan yang baik menjadi penting dalam operasi perusahaan. Selain itu service adalah kegiatan yang dapat diidentifikasikan dan tidak berwujud dan merupakan tujuan penting dari suatu rencana transaksi, guna memberikan kepuasan kepada konsumen (Erwin, 2011:72). Menurut Alma, (2012:90) mengemukakan pelayanan atau service adalah setiap kegiatan atau manfaat yang ditawarkan oleh suatu pihak kepada pihak lain dan pada dasarnya tidak berwujud dan tidak pula berakibat kepemilikian sesuatu dan produksinya dapat atau tidak dapat dikaitkan dengan suatu produk fisik. Menurut Siregar (2013:152) layanan adalah kegiatan pemberian jasa dari satu pihak kepada pihak lainnya. Pelayanan yang baik adalah pelayanan yang dilakukan secara ramah tamah, adil, cepat, tepat, dan etika yang baik sehingga memenuhi kebutuhan dan kepuasan bagi yang menerimanya. Moenir, (2012:27) layanan hakikatnya adalah serangkaian kegiatan, karena ia merupakan proses. Sebagai proses, layanan berlangsung secara rutin dan berkesinambungan meliputi seluruh kehidupan organisasi dalam masyarakat.Kasmir (2015:75), bahwa pelayanan diberikan sebagai tindakan atau perbuatan seseorang atau organisasi untuk memberikan kepuasan kepada pelanggan. Tindakan tersebut dapat dilakukan melalui cara langsung melayani pelanggan, artinya karyawan langsung berhadapan dengan pelanggan atau menempatkan sesuatu di mana pelanggan sudah tahu tempatnya atau pelayanan melalui telepon. Atau pelayanan yang tidak langsung oleh karyawan akan tetapi dilayani oleh mesin, seperti pengecekan billing melalui telepon. Tindakan yang dilakukan tersebut guna memenuhi keinginan pelanggan akan suatu produk atau jasa yang mereka butuhkan. Sugiarto (2012:36), menyatakan pelayanan adalah "suatu tindakan yang dilakukan untuk memenuhi kebutuhan orang lain yang tingkat kepuasan hanya dapat dirasakan oleh yang melayani maupun yang dilayani. Pelayanan terpadu satu atap". Dalam Keputusan Menteri PAN Nomor 63/KEP/M.PAN/7/2003, pengertian "pelayanan terpadu satu atap" adalah pola pelayanan yang diselenggarakan dalam satu tempat untuk berbagai jenis pelayanan yang tidak mempunyai keterkaitan proses dan dilayani melalui beberapa pintu, sedangkan "pelayanan satu pintu" adalah pola pelayanan yang diselenggarakan dalam satu tempat yang meliputi berbagai jenis pelayanan yang memiliki keterkaitan proses dan dilayani melalui satu pintu.

Keputusan Menteri PAN Nomor 63/KEP/M.PAN/7/2003 penyelenggaraan Pelayanan Terpadu Satu Pintu (PPTSP) adalah kegiatan penyelenggaraan jasa perizinan dan non-perizinan, yang proses pengelolaannya di mulai dari tahap permohonan sampai ke tahap penerbitan ijin dokumen, dilakukan secara terpadu dalam satu tempat. Dengan konsep ini, pemohon cukup datang ke satu tempat dan bertemu dengan petugas front office saja. Hal ini dapat meminimalisasikan interaksi antara pemohon dengan petugas perizinan dan menghindari pungutan-pungutan tidak resmi yang seringkali terjadi dalam proses pelayanan. Pembentukan Penyelenggaraan Pelayanan Terpadu Satu Pintu (PPTSP) pada dasarnya ditujukan untuk menyederhanakan birokrasi pelayanan perizinan dan non-perizinan dalam bentuk : a. Mempercepat waktu pelayanan dengan mengurangi tahapan-tahapan dalam pelayanan yang kurang penting. Koordinasi yang lebih baik juga akan 
sangat berpengaruh terhadap percepatan layanan perizinan.

b. Menekan biaya pelayanan izin usaha, selain pengurangan tahapan, pengurangan biaya juga dapat dilakukan dengan membuat prosedur pelayanan serta biaya resmi menjadi lebih transparan.

c. Menyederhanakan persyaratan izin usaha industri, dengan mengembangkan sistem pelayanan paralel dan akan ditemukan persyaratan-persyaratan yang tumpang tindih, sehingga dapat dilakukan penyederhanaan persyaratan. Hal ini juga berdampak langsung terhadap pengurangan biaya dan waktu.

d. Pelayanan perizinan dengan sistem terpadu satu pintu (one stop service) ini membuat waktu pembuatan izin menjadi lebih singkat. Pasalnya, dengan pengurusan administrasi berbasis teknologi informasi, input data cukup dilakukan sekali dan administrasi bisa dilakukan simultan.

Darmawan (2011:46) menjelaskan kualitas pelayanan yang dirasakan kosumen, terdapat beberapa faktor indikator, yaitu:

a. Faktor berwujud

Kualitas pelayanan secara langsung dalam bentuk fisik seperti kantor, perlengkapan, pelaratan dan alat penunjang lain yang membantu memperlancari proses pelayanan.

b. Faktor Keandalan

Adalah kemampuan dan keandalan untuk menyediakan pelayana yang terpercaya seperti kecermatan [etugas, standar pelayanan kemampuan petugas dan keahlian petugas dalam bekerja.

c. Faktor Ketanggapan

Adalah kesanggupan untuk membantu dan menyediakan pelayanan secara cepat datepat, seperti merespon pelanggan , petugas melakukan pelayanan cepat, petugas melakukan pelayanan tepat dan cermat

d. Faktor Jaminan

Adalah kemampuan dan keramahan serta sopan santunpegawai dalam membeirkan kepercayaan kepada konsumen, seperti memberikan jaminan tepat waktu, jaminan biaya dalam pelayanan, jaminan legalitas dan kepastian biayan pelayanan

e. Faktor Empati

Adalah sikap tegas tetapi penuh perhatian dari pegawai terhadap konsumen, seperti mendahulukan kepentingan pelanggan, melayani sikap ramah, melayani dengan sikap sopan santun, tidak deskriminatif dan menghargai pelanggan

Menurut Zeithhaml, Parasuraman \& Berry (dalam Hardiansyah 2011:46) untuk mengetahui kualitas pelayanan yang dirasakan secara nyata oleh konsumen, ada indikator kualitas pelayanan yang terletak pada lima dimensi kualitas pelayanan, yaitu:

1. Tangibles (berwujud) : kualitas pelayanan berupa sarana fisik perkantoran, komputerisasi administrasi, ruang tunggu, tempat informasi.

2. Realibility (kehandalan) : kemampuan dan keandalan untuk menyediakan pelayanan yang terpercaya.

3. Responsivess (ketanggapan) kesanggupan untuk membantu dan menyediakan pelayanan secara cepat dan tepat, serta tanggap terhadap keinginan konsumen.

4. Assurance (jaminan) : kemampuan dan keramahan serta sopan santun pegawai dalam meyakinkan kepercayaan konsumen.

5. Emphaty (Empati) : sikap tegas tetapi penuh perhatian dari pegawai terhadap konsumen.

Keputusan Menteri Pemberdayaan Aparatur Negara Pemerintah Nomor 96 Tahun 2012 pelaksanaan terhadap Kepmen Nomor KEP-25/M.PAN/2/2009 tanggal 24 pebruari 2009 terdapat 14 indikator pelayanan sebagai berikut:

1. Prosedur pelayanan yaitu kemudahan tahap pelayanan yang diberikan kepada masyarakat.

2. Persyaratan pelayanan yaitu persyaratan teknis dan administratif yang diperlukan untuk mendapatkan pelayana sesuai dengan jenis pelayanannya. 
3. Kejelasan petugas pelayanan yaitu keberadaan dan kepastian petugas yang memberikan pelayanan.

4. Kedisiplinan petugas pelayanan yaitu kesungguhan petugas dalam memberikan pelayanan terutama konsisten waktu kerja sesuai ketentuan yang berlaku.

5. Tanggungjawab petugas pelayanan yaitu kejelasan wewenang dan tanggung jawab dalam penyelenggaraan dan penyelesaian pelayanan.

6. Kemampuan petugas pelayanan yaitu tiingkat keahlian dan keterampilan yang dimiliki petugas dalam memberikan pelayanan.

7. Kecepatan pelayanan yaitu Target waktu pelayanan dapat diselesaikan dalam waktu yang ditentukan.

8. Keadilan dalam mendapatkan pelayanan yaitu pelaksanaan pelayanan dengan tidak membedakan golongan/stattus masyarakat yang dilayani.

9. Kesopanan dan keramahan petugas yaitu bentuk sikap dan perilaku petugas yang baik sopan dan ramah dalam memberikan pelayanan.

10. Kewajaran biaya pelayanan yaitu Keterjangkauan masyarakat terhadap besarnya biaya pelayanan.

11. Kepastian biaya pelayanan yaitu kesesuaian antara biaya yang dibayar dengan biaya yang ditetapkan.

12. Kepastian jadwal pelayanan yaitu aktivitas kerja yang disiplin terhadap pelaksanaan waktu pelayanan sesuai dengan ketentuan.

13. Kenyamanan lingkungan yaitu menyangkut kondisi sarana dan prasaran diberikan dengan nyaman kepada penerima layanan.

14. Keamanan pelayanan yaitu terjaminnya tingkat keamanan lingkungan unit penyelnggaraan pelayanan.

\subsubsection{Kepuasan Masyarakat}

Menurut Sumari (2011:24) menjelaskan bahwa kepuasan adalah tingkat perasaan seseorang setelah membandingkan kinerja (atau hasil) yang ia rasakan

dibandingkan dengan harapannya. Menurut Dewantara (2011:52) menjelaskan kepuasan adalah tingkat perasaan seseorang setelah membandingkan kinerja (atau hasil) yang ia rasakan dibandingkan dengan harapannya. Selama ini survei kepuasan masyarakat berpedoman pada Keputusan Menteri Pendayagunaan Aparatur Negara Nomor: KEP/25/M.PAN/2/2004 tentang Pedoman Umum Penyusunan Indeks Kepuasan Masyarakat Unit Pelayanan Instansi Pemerintah. Perangkat hukum tersebut belum mengacu pada UndangUndang Nomor 25 tahun 2009 tentang Pelayanan Publik dan Undang-Undang Nomor 12 Tahun 2011 tentang Pembentukan Peraturan Perundangan. Untuk menyesuaikan dengan kedua undang-undang tersebut, Kementerian Pendayagunaan Aparatur Negara dan Reformasi Birokrasi (PANRB) menerbitkan Peraturan Menteri PANRB No. 16/2014 tentang Pedoman Survei Kepuasan Masyarakat Terhadap Penyelenggaraan Pelayanan Publik. Unsur Indeks Kepuasan Masyarakat berdasarkan prinsip pelayanan sebagaimana telah ditetapkan dalam Keputusan Menteri Pendayagunaan Aparatur Negara Nomor No. 96/2012, yang kemudian dikembangkan menjadi 14 unsur yang relevan, valid, dan reliable, sebagai unsur minimal yang harus ada untuk dasar pengukuran indeks kepuasan masyarakat.

Survey Kepuasan Masyarakat Permen PANRB Nomor 16 Tahun 2014 menjelaskan bahwa Survey Kepuasan Masyarakat merupakan salah satu alat yang bisa digunakan oleh Unit Pelayanan Publik untuk mengevaluasi kinerja pelayanan yang dilaksanakan oleh unit tersebut. Kepuasan Masyarakat adalah tujuan utama yang harus dijadikan target oleh Unit Pelayanan Publik. Dengan mengadakan Survey Kepuasan Masyarakat, Unit Pelayanan dapat dengan mudah mengevaluasi kinerja unit dan mengetahui dengan pasti unsur mana saja yang masih perlu diperbaiki. Dalam mengadakan Survey Kepuasan Masyarakat, pada Peraturan Menteri Pendayagunaan 
Aparatur Negara Dan Reformasi Birokrasi Republik Indonesia Nomor 16 Tahun 2014 terdapat 9 unsur yang harus dijadikan pengukuran kepuasan masyarakat, yaitu :

1. Persyaratan, yaitu syarat yang harus dipenuhi dalam pengurusan suatu jenis pelayanan, baik persyaratan teknis maupun administratif.

2. Prosedur yaitu tata cara pelayanan yang dibakukan bagi pemberi dan penerima pelayanan, termasuk pengaduan.

3. Waktu pelayanan yaitu jangka waktu yang diperlukan untuk menyelesaikan seluruh proses pelayanan dari setiap jenis pelayanan.

4. Biaya/Tarif yaitu ongkos yang dikenakan kepada penerima layanan dalam mengurus dan/atau memperoleh pelayanan dari penyelenggara yang besarnya ditetapkan berdasarkan kesepakatan antara penyelenggara dan masyarakat.

5. Produk Spesifikasi Jenis Pelayanan yaitu hasil pelayanan yang diberikan dan diterima sesuai dengan ketentuan yang telah ditetapkan. Produk pelayanan ini merupakan hasil dari setiap spesifikasi jenis pelayanan.

6. Kompetensi Pelaksana yaitu kemampuan yang harus dimiliki oleh pelaksana meliputi pengetahuan, keahlian, keterampilan, dan pengalaman.

7. Perilaku Pelaksana yaitu sikap petugas dalam memberikan pelayanan.

8. Maklumat pelayanan merupakan pernyataan kesanggupan dan kewajiban penyelenggaran untuk melaksanakan pelayanan sesuai dengan standar pelayanan.

9. Menyangkut penanganan pengaduan, saran dan masukan adalah tata cara pelaksanaan pengaduan dan tindak lanjut.

Survei Kepuasan Masyarakat dilaksanakan sesuai dengan ketentuan dalam Peraturan Menteri Pendayagunaan Aparatur Negara dan Reformasi Birokrasi Nomor 14 Tahun 2017 tentang Pedoman Penyusunan Survei Kepuasan Masyarakat. Pedoman ini menggantikan pedoman sebelumnya dalam Permenpanrb No. 16 Tahun 2014 tentang
Pedoman Survei Kepuasan Masyarakat Terhadap Penyelenggaraan Pelayanan Publik. Peraturan sebelumnya dipandang tidak operasional dan memerlukan penjabaran teknis dalam pelaksanaannya. Sehingga perlu untuk disesuaikan dengan metode survei yang aplikatif dan mudah untuk dilaksanakan. Selain itu, Peraturan ini dimaksudkan untuk memberikan arahan dan pedoman yang jelas dan tegas bagi penyelenggara pelayanan publik.

\subsection{Penelitian Terdahulu}

1. Susilo W, 2014, Pengaruh Pelayanan Terhadap Kepuasan Masyarakat pada Polsek Banjarmasin Timur Kota Banjarmasin. Penelitian ini bertujuan untuk mengetahui implementasi pelayanan terhadap indek kepuasan masyarakat terhadap kepuasan masyarakat. Penelitian ini menggunakan jenis penelitian kuantitatif, dengan teknik pengumpulan data melalui observasi, wawancara, dokumentasi dan angket. Kesimpulan dari penelitian ini adalah indikator pelayanan yang terdiri dari berwujud (tangible), kehandalan (reliability), ketanggapan (responsiviness), jaminan (assurance) dan empati (empahty) semua variabel kualitas layanan berpengaruh signifikan baik secara simultan maupun secara parsial terhadap kepuasan masyarakat. Persamaan penelitian ini dengan penulis adalah sama-sama mengangkat masalah manajemen SDM, keterkaitan variabel yang diteliti sedangkan perbedaannya adalah obyek yang diteliti, waktu penelitian.

2. Murhani Abdullah, 2011, Analisis Kualitas Pelayanan Terhadap Kepuasan Masyarakat Pada Kecamatan Kusan Hilir Kabupaten Tanah Bumbu. Penelitian tersebut bertujuan untuk mengetahui kualitas pelayanan masyarakat di Kusan Hilir Kabupaten Tanah Bumbu. Peneliti menggunakan jenis penelitian kuantitatif, dengan teknik pengumpulan data melalui observasi, wawancara dan dokumentasi serta angket. Kesimpulan dari penelitian tersebut bahwa indikator kualitas pelayanan publik yang terdiri dari 
berwujud (tangible), kehandalan (reliability), ketanggapan (responsiviness), jaminan (assurance) dan empati (empahty) di Kusan Hilir Kabupaten Tanah Bumbu belum cukup baik dlihat dari indikator kualitas pelayanan seperti tersedia bangunan dan fasilitas ruang tunggu, tetapi masih banyak masyarakat yang mengeluhkan bangunan kantor dan ruang tunggu belum memadai, masyarakat telah telah mendapatkan pelayanan sesuai dengan prosedur dan ketepatan waktu. Berdasarkan hasil penelitian secara simultan dan parsial semua variabel berpengaruh signfikan terhadap kepuasan masyarakat. Persamaan penelitian Murhani Abdullah dengan penulis adalah sama-sama mengangkat masalah manajemen SDM, keterkaitan variabel yang diteliti sedangkan perbedaannya adalah obyek yang diteliti, waktu penelitian.

3. Syamsir Alam, 2014, Pengaruh Kualitas Pelayanan Terhadap Kepuasan Masyarakat Pada Kantor Keluaran Pengambangan Kota Banjarmasin. Teknik analisis yang digunakan kuantitatif dengan sampel sebanyak 100 responden dan hasil dalam penelitiannya terlihat indikator pelayanan yang terdiri dari berwujud (tangible), kehandalan (reliabelity), ketanggapan (responsiviness), jaminan (assurance) dan empati (emphaty) secara uji regresi diketahui semua variabel baik secara parsial dan simultan berpengaruh signifikan terhadap kepuasan masyarakat. Persamaan penelitian adalah sama-sama mengangkat masalah SDM khususnya tentang pelayanan. Sedangkan perbedaanya adalah obyek yang diteliti, waktu pelaksanaan penelitian dan materi yang dikemukakan.

\section{KERANGKA KONSEPTUAL DAN HIPOTESIS}

\subsection{Kerangka Konseptual}

Kerangka konseptual merupakan susunan atau rangkaian dari variabel bebas dan terikat, dalam menjelaskan mana yang termasuk dependent maupun independent. sebagai variabel bebas yakni label $\mathrm{x}$, dan variable terikat dengan label $Y$. Berdasarkan hal tersebut dalam penelitian ini yang termasuk dalam variable bebas adalah faktor kualitas layanan (X) yang terdiri dari variabel berwujud (tangible), kehandalan (reliability), ketanggapan (responsibility), jaminan (assurance) dan empati (empathy) dan untuk variable terikat adalah variable kepuasan masyarakat (Y). Pada penelitian ini bermaksud untuk menjelaskan pengaruh antar variabel melalui pengujian hipotesis dan sekaligus melakukan eksplanasi terhadap beberapa variabel, maka sifat penelitian ini adalah penelitian eksplanatori (explanatory research). Berdasarkan hal tersebut, maka kerangka konseptual yang digunakan dalam penelitian ini adalah sebagai berikut :

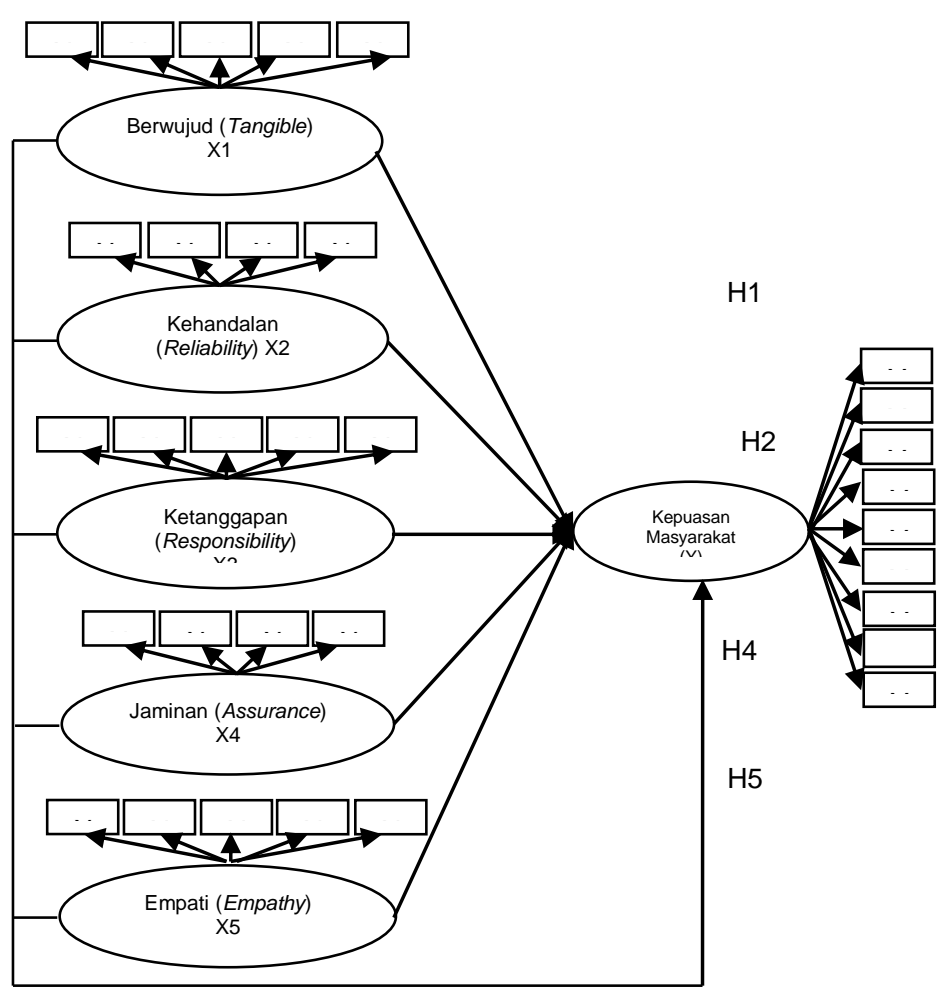

Gambar 3.1: Kerangka Konseptual

Sumber : Data Diolah

\subsection{Hipotesis Penelitian}

Adapun hipotesis dalam penelitian ini dapat dijelaskan sebagai berikut, yaitu;
1. Variabel
berwujud
(tangible)
berpengaruh signifikan terhadap kepuasan masyarakat pada Polres Hulu 
Sungai Tengah (HST) Kalimantan Selatan.

2. Variabel kehandalan (reliability) berpengaruh signifikan terhadap kepuasan masyarakat pada Polres Hulu Sungai Tengah (HST) Kalimantan Selatan.

3. Variabel ketanggapan (responsibility) berpengaruh signifikan terhadap kepuasan masyarakat pada Polres Hulu Sungai Tengah (HST) Kalimantan Selatan.

4. Variabel jaminan (assurance) berpengaruh signifikan secara parsial terhadap kepuasan masyarakat pada Polres Hulu Sungai Tengah (HST) Kalimantan Selatan.

5. Variabel empati (empathy) berpengaruh signifikan terhadap kepuasan masyarakat pada Polres Hulu Sungai Tengah (HST) Kalimantan Selatan.

6. Variabel berwujud (tangible), kehandalan (reliability), ketanggapan (responsibility), jaminan (assurance) dan empati (empathy) berpengaruh signifikan secara simultan terhadap kepuasan masyarakat pada Polres Hulu Sungai Tengah (HST) Kalimantan Selatan.

\section{METODE PENELITIAN}

\subsection{Rancangan Penelitian}

Penelitian ini dilaksanakan dengan maksud menjelaskan hubungan kausal dan menguji keterkaitan antara fakta-fakta dari variable kualitas layanan terhadap kepuasan masyarakat (Y). Singarimbun \& Efendi (2005:90) menyatakan bahwa penelitian penjelasan merupakan bagian dari penelitian survey, dimana penalitian survey dapat digunakan untuk maksud penjajakan, deskriptif, penjelasan atau konfirmasi, evaluasi, prediksi, operasional, dan pengembangan indikator. Jenis penelitian yang termasuk kategori penelitian survey yaitu penelitian yang mengambil sample dari populasi dan menggunakan kuesioner sebagai alat pengumpul data yang utama. Informasi primer berkenaan dengan variabel penelitian ini dikumpulkan dengan teknik angket/kuesioner.

\subsection{Definisi Operasional Variabel}

Adapun variabel-variabel yang dikumpulkan dalam penelitian ini adalah sebagai berikut:

1. Layanan (X) adalah kegiatan pemberian jasa dari satu pihak kepada pihak lainnya. Pelayanan yang baik adalah pelayanan yang dilakukan secara ramah tamah, adil, cepat, tepat, dan etika yang baik sehingga memenuhi kebutuhan dan kepuasan bagi yang menerimanya.

2. Menurut Zeithhaml, Parasuraman \& Berry (dalam Hardiansyah 2011:46) untuk mengetahui kualitas pelayanan yang dirasakan secara nyata oleh konsumen, ada indikator dari faktor kualitas pelayanan yang terletak pada lima dimensi kualitas pelayanan, yaitu:

1) Berwujud (tangibles) (X1) kualitas pelayanan berupa sarana fisik perkantoran, komputerisasi administrasi, ruang tunggu, tempat informasi.

2) Kehandalan (realibility) (X2) kemampuan dan keandalan untuk menyediakan pelayanan yang terpercaya.

3) Ketanggapan (responsibility) (X3) kesanggupan untuk membantu dan menyediakan pelayanan secara cepat dan tepat, serta tanggap terhadap keinginan konsumen.

4) Jaminan (assurance) (X4) kemampuan dan keramahan serta sopan santun pegawai dalam meyakinkan kepercayaan konsumen.

5) Empati (empathy) (X5) sikap tegas tetapi penuh perhatian dari pegawai terhadap konsumen.

3. Variabel kepuasan masyarakat (Y) adalah tingkat perasaan seseorang setelah membandingkan kinerja (atau hasil) yang ia rasakan dibandingkan dengan harapannya. Peraturan Menteri Pendayagunaan Aparatur Negara dan Reformasi Birokrasi Nomor 14 Tahun 2017 tentang Pedoman Penyusunan Survei Kepuasan Masyarakat menjelaskan unsur-unsur yang menjadi fokus dalam pelaksanaan 
Survei Kepuasan Masyarakat terdiri dari 9 unsur

\subsection{Jenis dan Sumber data Penelitian}

\subsubsection{Jenis Data}

Adapun jenis data dalam penelitian ini yang penulis ambil, yaitu sebagai berikut:

1. Data Kualitatif, yaitu berupa data atau informasi yang tidak berbentuk angka. Penulis mengangkat data tersebut dari hasil wawancara dengan pihak Polres Hulu Sungai Tengah (HST) Kalimantan Selatan, yakni berupa data tentang sejarah instansi, struktur organisasi, bidang operasional yang dilakukan atau proses kerja.

2. Data Kuantitatif yaitu data yang berbentuk angka, yang diangkat dari dokumen instansi dalam hal ini tentang data jumlah pegawai dan orang masyarakat, data tabulasi dan data lain yang berhubungan dengan penelitian.

\subsubsection{Sumber Data}

Sumber data dalam penelitian ini terdiri dari sumber data primer dan sumber data sekunder, adapun uraian data sumber data tersebut, yaitu:

1. Data Primer merupakan data penelitian yang diperoleh secara langsung dari sumber asli secara khusus di kumpulkan oleh peneliti untuk menjawab pertanyaan yang diajukan melalui daftar pertanyaan.

2. Data Sekunder merupakan data penelitian yang diperoleh secara tidak langsung melalui media perantara seperti informasi dan publikasi atau laporan historis yang telah tersusun dalam dokumen/arsip.

\subsection{Populasi dan Sampel}

\subsubsection{Populasi}

Populasi merupakan seluruh obyek yang hendak diteliti. (Amirin dan Tatang (2011:987) dan menurut Umar, (2001:78) populasi adalah keseluruhan obyek penelitian. Berdasarkan pemahaman dari landasan teori tersebut, maka populasi dari penelitian ini ditetapkan adalah para masyarakat yang melakukan pengurusan dokumen di Polres Hulu Sungai Tengah (HST) Kalimantan Selatan, yakni yang ditentukan sebanyak 100 orang.

\subsubsection{Sampel}

Menurut Amirin dan Tatang (2011:98) teknik pengambilan sampel dalam penelitian ini menggunakan teknik Quota Sampling, yaitu penarikan sampel yang tidak diketahui jumlah populasi yang hendak diteliti/dijadikan sampel, sehingga penentuan sampelnya ditentukan terlebih dahulu berdasarkan kuota/target yang dinginkan, jika pengumpulan data belum memenuhi kuota/target yang diinginkan maka pengumpulan data dan penelitian belum selesai, hingga kuota/terget terpenuhi. Berdasarkan hal tersebut, maka kuota/target menurut Tatangmanguny. Wordpress.com, maka sampel penelitian ini ditentukan sebanyak 100 responden.

\subsection{Teknik Pengumpulan Data}

1. Studi kepustakaan, yaitu pengumpulan data melalui mempelajari berbagai literatur dan bahan bacaan yang berhubungan dengan permasalahan.

2. Observasi,yaitu pengumpulan data melalui pengamatan secara umum pada para pegawai dan masyarakat diwilayah kerja Polres Hulu Sungai Tengah (HST) Kalimantan Selatan sebagai dasar untuk mengidentifikasi permasalahan yang akan dibahas.

3. Wawancara, yaitu mengumpulkan data dengan mengadakan tanyajawab secara lisan dengan pihak para pegawai dan masyarakat di wilayah kerja Polres Hulu Sungai Tengah (HST) Kalimantan Selatan pada waktu yang telah ditentukan.

4. Dokumentasi, yaitu teknik pengumpulan data melalui pencatatan dan pengumpulan data pada Polres Hulu Sungai Tengah (HST) Kalimantan Selatan yang berkaitan dengan permasalahan yang akan dibahas.

5. Kuesioner, yaitu pengumpulan data dengan cara membagikan daftar pertanyaan secara tertulis kepada masyarakat. Untuk memperoleh data primer yang diperlukan dalam penyusunan tesis ini.

\subsection{Teknik Analisis Data}

Dalam penelitian ini teknik pengolahan data yang akan dilakukan oleh penulis adalah dengan menggunakan kuantitatif yakni analisis bertujuan untuk membuat 
diskripsi, gambaran atau lukisan secara sistematis, faktual dan akurat mengenai fakta-fakta, sifat-sifat serta hubungan antar fenomena yang diselidiki secara terperinci untuk menghasilkan rekomendasi untuk keperluan di masa yang akan datang. Analisis data dilakukan berdasarkan data primer yang diperoleh langsung melalui penyebaran kuisioner kepada responden yang selanjutnya akan dianalisis dengan analisis regresi berganda bantuan program SPSS (statistic produk service solution) Versi 17 for windows. Sedangkan alat uji yang digunakan dalam penelitian ini menurut Umar, (2001:83) adalah sebagai berikut:

\subsubsection{Uji Instrumen Penelitian}

\section{Uji Validitas}

Adapun penentuan atau pengambilan keputusan untuk valid instrumen pertanyaan dengan menentukan table $\mathrm{r}$ (Pearson Product Moment) uji 2 sisi dengan taraf signifikan 0,05. Berdasarkan hal itu bila dibandingkan antara adalahJika rhitung positif dan $r_{\text {hitung }}>r_{\text {tabel }}$ maka instru ment tersebut valid. Jika rtabel negative dan $r_{\text {hitung }}<r_{\text {tabel }}$ maka instrument tersebut tidak valid.

\section{Uji Reliabilitas}

Variabel dikatakan reliabel jika memberikan nilai Cronbach $\mathrm{A}_{\text {lpha }}>0,60$. (Umar, 2001, 41-42). Setelah dilakukan pengujian reliabilitas maka hasil dari jawaban kuesioner adalah reliabel.

\subsubsection{Uji Asumsi Klasik}

\section{Uji Multikolinearitas}

Multikolineritas dapat diketahui dengan memeriksa nilai VIF (variance inflation factor) yang merupakan unsure diagonal invers matrk korelasi sederhana antara perubah bebas. Apabila beberapa nilai VIF lebih dari $10 \mathrm{mk}$ multikolienearitas adalah sebuah masalah.

\section{Uji Heteroskedastisitas}

Jika diagram pencar yang membentuk pola-pola tertentu yang teratur maka regresi mengalami gangguan heteroskedastisitas. Jika diagram pencar tidak membentuk pola atau acak maka regresi tidak mengalami gangguan heteroskedastisitas.

\section{Uji Normalitas (kenormalan)}

Bilamana hasil plot menujukkan pola garis lurus mendekati $45^{\circ}$ berarti asumsi normalitas terpenuhi.

\subsubsection{Uji Hipotesis}

\section{Analisis Regresi Linier Berganda}

Analisis data dilakukan berdasarkan data primer yang diperoleh langsung dari penyebaran kuisioner kepada masyarakat. Untuk menguji hipotesa dalam penelitian ini menggunakan analisis regresi linier berganda. Adapun rumus dari regresi linier berganda adalah :

$$
\begin{gathered}
\mathrm{Y}=\mathrm{a}+\boldsymbol{\beta} 1 . \mathrm{X} 1+\beta 2 . \mathrm{X} 2+\beta 3 . \mathrm{X3}+\beta 4 . \mathrm{X} 4+\beta 5 . \mathrm{X5} \\
+\varepsilon
\end{gathered}
$$

\section{Uji F (simultan)}

Menarik kesimpulan, yaitu $\mathrm{H}_{0}$ diterima atau ditolak berdasarkan pada hasil perbandingan antara $F_{\text {hitung dengan }} F_{\text {tabel }}$ dengan kreteria pengujian Apabila $F_{h i t u n g}>$ $\mathrm{F}_{\text {tabel}}$, maka $\mathrm{H}_{0}$ ditolak dan $\mathrm{H}_{1}$ diterima. Apabila $F_{\text {hitung }}<\mathrm{F}_{\text {tabel }}$, maka $\mathrm{H}_{0}$ diterima dan $\mathrm{H}_{1}$ ditolak.

\section{Uji Parsial (Uji t)}

Menarik kesimpulan yaitu $\mathrm{H}_{0}$ diterima atau ditolak berdasarkan pada hasil perbandingan antara $t_{\text {hitung }}$ dengan $t_{\text {tabel }}$ dengan kreteria pengujian Apabila $t_{\text {hitung }}>$ $\mathrm{t}_{\text {tabel}}$, maka $\mathrm{H}_{0}$ ditolak dan $\mathrm{H}_{1}$ diterima. Apabila $\mathrm{t}_{\text {hitung }}<\mathrm{t}_{\text {tabel }}$, maka $\mathrm{H}_{0}$ diterima dan $\mathrm{H}_{1}$ ditolak.

\section{Uji Variabel Dominan}

Uji dominan digunakan indikator koefisien beta standardized dari variabel-variabel dari model regresi. Koefisien beta standardized diperoleh dari hasil perkalian antara koefisien parsial korelasi $\left(\mathrm{SDx}_{1} / \mathrm{Sdy}\right)$ dan koefisien variabelnya (bi).

\section{ANALISIS HASIL PENELITIAN DAN PEMBAHASAN}

\subsection{Analisis Hasil Penelitian \\ 5.1.1. Pengujian Instrumen Penelitian \\ 1. Hasil Uji Validitas}

Uji validitas dapat diketahui dengan melihat nilai $\mathrm{r}_{\text {hitung dan }}$ untuk mengetahui validitas instrument pertanyaan harus dibandingkan dengan $r_{\text {tabel }}$ pada $\alpha 0,05$. Berikut hasil uji validitas masing-masing variabel sebagai berikut: 
Tabel 5.11

Uji Validitas Berwujud (Tangible) (X1)

\begin{tabular}{|c|c|c|}
\hline Variable & $\begin{array}{c}\text { rhitung } \\
\text { (lihat lampiran } \\
\text { 3) }\end{array}$ & $\begin{array}{c}\text { Rtabel } \\
\text { (lihat lampiran } \\
\text { 6) }\end{array}$ \\
\hline $\mathrm{X} 1.1$ & $0,448(* *)$ & 0,203 \\
$\mathrm{X} 1.2$ & $0,466(* *)$ & 0,203 \\
$\mathrm{X} 1.3$ & $0,508(* *)$ & 0,203 \\
$\mathrm{X} 1.4$ & $0,511(* *)$ & 0,203 \\
X1.5 & $0,456(* *)$ & 0,203 \\
\hline
\end{tabular}

Sumber : Data spss diolah

Hasil uji validitas terhadap instrumen pertanyaan berwujud (tangible) (X1) pada Polres Hulu Sungai Tengah (HST) Kalimantan Selatan yang diajukan dapat disimpulkan bahwa semua instrumen pertanyaan tersebut valid ini terbukti dengan membandingkan ( $\mathrm{r}_{\text {hitung }}$ ) dengan rtabel pada $\alpha$ 0,05 yang mana diambil keputusan jika nilai rhitung positip dan $r_{\text {hitung }}>r_{\text {tabel }}$, maka instrumen pertanyaan tersebut valid.

Tabel 5.12

Uji Validitas Kehandalan (Reliability) (X2)

\begin{tabular}{|c|c|c|}
\hline Variable & $\begin{array}{c}\text { rhitung } \\
\text { (lihat } \\
\text { lampiran 3) }\end{array}$ & $\begin{array}{c}\text { Rtabel } \\
\text { (lihat lampiran } \\
6)\end{array}$ \\
\hline $\mathrm{X} 2.1$ & $0,490(* *)$ & 0,203 \\
$\mathrm{X} 2.2$ & $0,471(* *)$ & 0,203 \\
$\mathrm{X} 2.3$ & $0,550(* *)$ & 0,203 \\
$\mathrm{X} 2.4$ & $0,422(* *)$ & 0,203 \\
\hline
\end{tabular}

Sumber : Data spss diolah

Hasil uji validitas terhadap instrumen pertanyaan variabel kehandalan (reliability) (X2) yang diajukan pada Polres Hulu Sungai Tengah (HST) Kalimantan Selatan dapat disimpulkan bahwa semua instrumen pertanyaan tersebut valid ini terbukti dengan membandingkan ( $\mathrm{r}_{\text {hitung }}$ ) dengan rtabel pada $\alpha 0,05$ yang mana diambil keputusan jika nilai rhitung positip dan $r_{\text {hitung }}>r_{\text {tabel }}$, maka instrumen pertanyaan tersebut valid.
Tabel 5.13

Uji Validitas

Variabel Ketanggapan (Responsibility)

(X3)

\begin{tabular}{|c|c|c|}
\hline Variable & $\begin{array}{c}\text { rhitung } \\
\text { (lihat lampiran } \\
\text { 3) }\end{array}$ & $\begin{array}{c}\text { Rtabel } \\
\text { (lihat } \\
\text { lampiran 6) }\end{array}$ \\
\hline X3.1 & $0,500(* *)$ & 0,203 \\
X3.2 & $0,411(* *)$ & 0,203 \\
X3.3 & $0,451(* *)$ & 0,203 \\
X3.4 & $0,444(* *)$ & 0,203 \\
X3.5 & $0,501(* *)$ & 0,203 \\
\hline
\end{tabular}

Sumber : Data spss diolah

Hasil uji validitas terhadap instrumen pertanyaan variabel ketanggapan (responsibility) (X3) yang diajukan pada Polres Hulu Sungai Tengah (HST) Kalimantan Selatan dapat disimpulkan bahwa semua instrumen pertanyaan tersebut valid ini terbukti dengan membandingkan ( $r_{\text {hitung }}$ ) dengan rtabel pada $\alpha 0,05$ yang mana diambil keputusan jika nilai rhitung positip dan $r_{\text {hitung }}>r_{\text {tabel }}$, maka instrumen pertanyaan tersebut valid.

Table 5.14

Uji Validitas Jaminan (Assurance) (X4)

\begin{tabular}{|c|c|c|}
\hline Variable & $\begin{array}{c}\text { rhitung } \\
\text { (lihat lampiran 3) }\end{array}$ & $\begin{array}{c}\text { Rtabel } \\
\text { (lihat lampiran } \\
6)\end{array}$ \\
\hline X4.1 & $0,490(* *)$ & 0,203 \\
X4.2 & $0,512(* *)$ & 0,203 \\
X4.3 & $0,501(* *)$ & 0,203 \\
X4.4 & $0,467(* *)$ & 0,203 \\
\hline
\end{tabular}

Sumber : Data spss diolah

Hasil uji validitas terhadap instrumen pertanyaan jaminan (assurance) (X4) yang diajukan pada Polres Hulu Sungai Tengah (HST) Kalimantan Selatan dapat disimpulkan bahwa semua instrumen pertanyaan tersebut valid ini terbukti dengan membandingkan ( $\mathrm{r}_{\text {hitung }}$ ) dengan rtabel pada $\alpha$ 0,05 yang mana diambil keputusan jika nilai rhitung positip dan $\mathrm{r}_{\text {hitung }}>\mathrm{r}_{\text {tabel }}$, maka instrumen pertanyaan tersebut valid. 
Tabel 5.15

Uji Validitas Empati (Empathy) (X5)

\begin{tabular}{|c|c|c|}
\hline Variable & $\begin{array}{c}\text { rhitung } \\
\text { (lihat lampiran 3) }\end{array}$ & $\begin{array}{c}\text { Rtabel } \\
\text { (lihat lampiran } \\
\text { 6) }\end{array}$ \\
\hline X3.1 & $0,444(* *)$ & 0,203 \\
X3.2 & $0,420(* *)$ & 0,203 \\
X3.3 & $0,481(* *)$ & 0,203 \\
X3.4 & $0,499(* *)$ & 0,203 \\
X3.5 & $0,405(* *)$ & 0,203 \\
\hline
\end{tabular}

Sumber : Data spss diolah

Hasil uji validitas pertanyaan variabel Empati (Empathy) (X5) yang diajukan pada Polres Hulu Sungai Tengah (HST) Kalimantan Selatan dapat disimpulkan bahwa semua instrumen pertanyaan tersebut valid ini terbukti dengan membandingkan ( $\mathrm{r}_{\text {hitung }}$ ) dengan rtabel pada $\alpha 0,05$ yang mana diambil keputusan jika nilai rhitung positip dan $r_{\text {hitung }}>r_{\text {tabel}}$, maka instrumen pertanyaan tersebut valid.

\section{Table 5.16}

\section{Uji Validitas Kepuasan Masyarakat}

(Y)

\begin{tabular}{|c|c|c|}
\hline Variable & $\begin{array}{c}\text { rhitung } \\
\text { (lihat lampiran 3) }\end{array}$ & $\begin{array}{c}\text { Rtabel } \\
\text { (lihat lampiran } \\
6)\end{array}$ \\
\hline Y1.1 & $0,455(* *)$ & 0,203 \\
Y1.2 & $0,489(* *)$ & 0,203 \\
Y1.3 & $0,511(* *)$ & 0,203 \\
Y1.4 & $0,502(* *)$ & 0,203 \\
Y1.5 & $0,455(* *)$ & 0,203 \\
Y1.6 & $0,480(* *)$ & 0,203 \\
Y1.7 & $0,440(* *)$ & 0,203 \\
Y1.8 & $0,456(* *)$ & 0,203 \\
Y1.9 & $0,457(* *)$ & 0,203 \\
\hline
\end{tabular}

Sumber : Data spss diolah

Hasil uji validitas terhadap instrumen pertanyaan kepuasan masyarakat (Y) yang diajukan pada Polres Hulu Sungai Tengah (HST) Kalimantan Selatan dapat disimpulkan bahwa semua instrumen pertanyaan tersebut valid ini terbukti dengan membandingkan ( $\mathrm{r}_{\text {hitung}}$ ) dengan rtabel pada $\alpha$ 0,05 yang mana diambil keputusan jika nilai rhitung positip dan $r_{\text {hitung }}>r_{\text {tabel}}$, maka instrumen pertanyaan tersebut valid.

\section{Uji Reliabilitas}

Suatu konstruk atau variabel dikatakan reliabel jika memberikan nilai Cronbach Alpha minimum 0,5. (Santoso, 2004, 280). Suatu konstruk atau variabel dikatakan reliabel jika memberikan nilai Cronbach $A_{\text {lpha }}>0,60$. (Ghozali, 2006, 41-42). Setelah dilakukan pengujian reliabilitas maka hasil dari jawaban kuesioner adalah reliabel.

Berikut ringkasan hasil uji reliabilitas instrumen dalam penelitian ini.

Tabel 5.17

Hasil Uji Reliabilitas

\begin{tabular}{|l|c|c|}
\hline \multicolumn{1}{|c|}{ Variable } & $\begin{array}{c}\text { Cronbach } \\
\mathrm{A}_{\text {lpha }} \\
\text { (lihat } \\
\text { lampiran 4) }\end{array}$ & $\begin{array}{c}\text { Nilai } \\
\text { Baku }\end{array}$ \\
\hline Berwujud (tangible) (X1) & 0,643 & 0,60 \\
Kehandalan (reliability) & 0,659 & 0,60 \\
(X2) & 0,666 & 0,60 \\
Ketanggapan & 0,670 & 0,60 \\
(responsibility) (X3) & 0,664 & 0,60 \\
Jaminan (assurance) (X4) & 0,669 & 0,60 \\
Empati (empathy) (X5) & & \\
kepuasan masyarakat (Y) & & \\
\hline
\end{tabular}

Sumber: Data spss diolah

\subsubsection{Pengujian Asumsi Klasik}

\section{Uji Multikolinearitas}

Uji multikolinearitas bertujuan untuk menguji apakah model regresi yang digunakan telah di temukan adanya korelasi (hubungan) antara variabel bebas (independent) yang satu dengan variabel bebas yang lainnya. Model regresi yang baik seharusnya tidak terjadi korelasi antara variabel bebas. Regresi yang bebas multikolinearitas ditandai dengan nilai VIF berkisar angka 1 dan nilai Tolerance berkisar angka 1 (VIF $=1 /$ tolerance) (Pratisto, 2004, 161) dan menurut Solimun (2004, 35) apabila beberapa nilai VIF lebih dari 5, maka multikolinearitas adalah sebuah masalah.

Tabel 5.18

Analisis Multikolinearitas

\begin{tabular}{|l|c|c|}
\hline \multirow{2}{*}{\multicolumn{1}{|c|}{ Variabel }} & \multicolumn{2}{c|}{$\begin{array}{c}\text { Collinierarity } \\
\text { Statistic's }\end{array}$} \\
\cline { 2 - 3 } Tolerance & VIF \\
\hline Berwujud (X1) & 0,999 & 1,430 \\
\hline Kehandalan (X2) & 0,989 & 1,234 \\
\hline Ketanggapan (X3) & 0,981 & 1,193 \\
\hline Jaminan (X4) & 0,980 & 1,098 \\
\hline Empati (X5) & 0,998 & 1,304 \\
\hline
\end{tabular}

Sumber: Lampiran 5

Hasil perhitungan nilai tolerance pada tabel diatas menunjukkan nilai yang mendekati 
angka 1 dan nilai variance inflation factor (VIF) diatas menunjukkan tidak ada satu variabel bebas yang memiliki nilai VIF tidak lebih dari 10. Jadi dapat disimpulkan asumsi tidak disifat adanya gejala multikolinearitas antar variabel bebas.

\section{Uji Heteroskedastisitas}

Adapun hasil heteroskedastisitas tersebut, adalah:

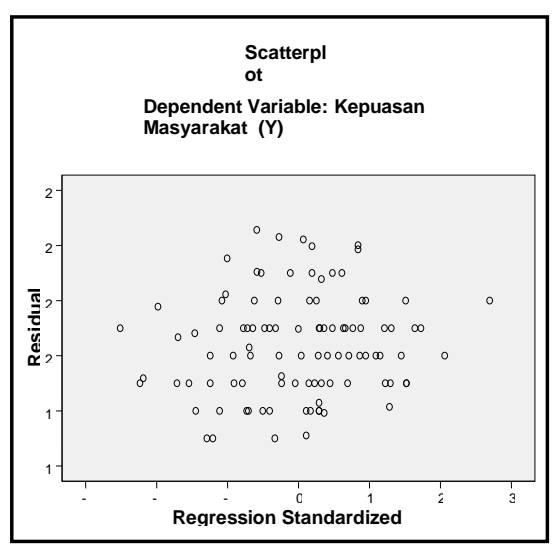

Dalam diagnose heteroskedastisitas di penelitian ini menghasilkan grafik scatterplot menghasilkan penyebaran dalam bentuk pola atau acak, maka hal ini dapat disimpulkan bahwa regresi layak dipergunakan.

\section{Uji Normalitas (kenormalan)}

Berdasakan hasil pengujian dengan SPSS, diperoleh grafik Plot of Regression, yaitut: Gambar 5.3 : Grafik Plot of

\section{Regression}

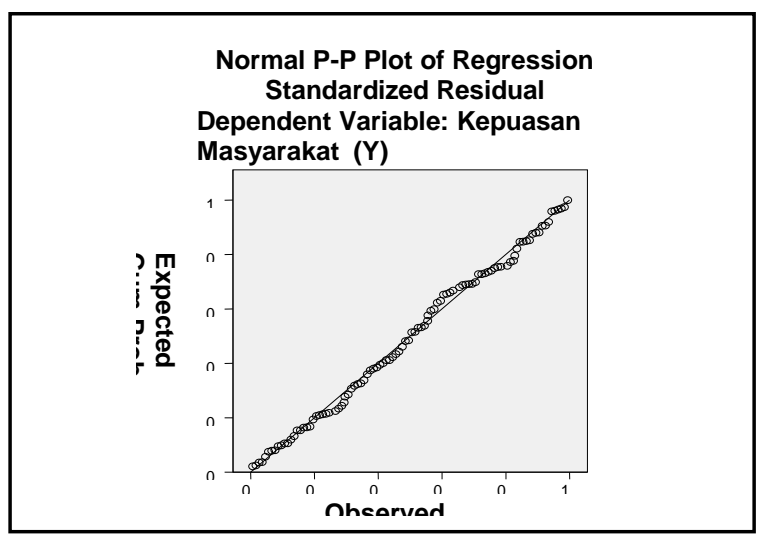

Sumber : Lampiran 5

Terlihat titik penyebaran disekitar garis diagonal / menunjukkan pola garis lurus mendekati sudut $45^{\circ}$, maka di dapat bahwa semua data berdistribusi normal, sehingga asumsi normalitas terpenuhi.

\section{Uji Hipotesis Kedua}

Untuk menguji hipotesis kedua secara parsial langkah yang perlu dilakukan adalah dengan membandingkan nilai thitung dengan ttable pada taraf nyata $5 \%$. Jika thitung > ttable maka pengaruhnya signifikan. Untuk mendapatkan ttabel digunakan tabel distribusi t untuk tingkat signifikasi 5\% dengan Degrees of Freedom (df) $=$ n-k maka didapat df adalah (100-6)= 95 dengan demikian ttabel adalah sebesar 1,646. Variabel kehandalan (reliability) (X2) berpengaruh signifikan terhadap kepuasan masyarakat (Y) hal ini didasarkan pada perbandingan antara thitung 4,197 dan ttabel 1,646 dan mempunyai nilai probabilitas sebesar $p<$ 0,05 yaitu $0,001<0,05$, berarti terdapat pengaruh antara variabel kehandalan (reliabelity), (X2) dengan variabel terikat kepuasan masyarakat (Y). Besarnya pengaruh dari variabel kehandalan (reliabelity) (X2) terhadap kepuasan masyarakat (Y) dapat diketahui dari Standardized Coefficients Beta 0,720 (lihat tabel 5.19) yang berarti kehandalan (reliabelity) (X2) memberikan pengaruh terhadap kepuasan masyarakat (Y) sebesar $72 \%$.

\section{Uji Hipotesis Ketiga}

Untuk menguji hipotesis ketiga secara parsial langkah yang perlu dilakukan adalah dengan membandingkan nilai thitung dengan ttable pada taraf nyata $5 \%$. Jika thitung > ttable maka pengaruhnya signifikan. Untuk mendapatkan ttabel digunakan tabel distribusi t untuk tingkat signifikasi 5\% dengan Degrees of Freedom $(\mathrm{df})=\mathrm{n}-\mathrm{k}$ maka didapat df adalah (100-6)= 95 dengan demikian ttabel adalah sebesar 1,646. Sehubungan dengan hal tersebut, maka variabel ketanggapan (responsibility) (X3) berpengaruh signifikan terhadap kepuasan masyarakat (Y) hal ini didasarkan pada perbandingan antara thitung 3,563 dan ttabel 1,646 dan mempunyai nilai probabilitas sebesar $p<$ 0,05 yaitu $0,002<0,05$, berarti terdapat pengaruh antara variabel ketanggapan (responsibility) (X3) dengan variabel terikat kepuasan masyarakat (Y). Besarnya pengaruh dari variabel ketanggapan (responsibility) (X3) terhadap kepuasan 
masyarakat (Y) dapat diketahui dari Standardized Coefficients Beta 0,642 yang berarti ketanggapan (responsibility) ini memberikan pengaruh terhadap kepuasan masyarakat (Y) sebesar 64,2\%.

\section{Uji Hipotesis Keempat}

Untuk menguji hipotesis keempat secara parsial langkah yang perlu dilakukan adalah dengan membandingkan nilai thitung dengan ttable pada taraf nyata $5 \%$. Jika thitung > ttable maka pengaruhnya signifikan. Untuk mendapatkan ttabel digunakan tabel distribusi t untuk tingkat signifikasi 5\% dengan Degrees of Freedom $(\mathrm{df})=\mathrm{n}-\mathrm{k}$ maka didapat $\mathrm{df}$ adalah (100-6)= 95 dengan demikian ttabel adalah sebesar 1,646. Maka dapat diuji akan variabel jaminan (assurance) (X4) berpengaruh signifikan terhadap kepuasan masyarakat (Y) hal ini didasarkan pada perbandingan antara thitung 3,320 dan ttabel 1,646 dan mempunyai nilai probabilitas sebesar $p<$ 0,05 yaitu $0,002<0,05$, berarti terdapat pengaruh antara variabel jaminan (assurance) (X4) dengan variabel terikat kepuasan masyarakat (Y). Besarnya pengaruh dari variabel jaminan (assurance) (X4) terhadap kepuasan masyarakat (Y) dapat diketahui dari Standardized Coefficients Beta 0,610 yang berarti jaminan (assurance) (X4) ini memberikan pengaruh terhadap kepuasan masyarakat (Y) sebesar $61 \%$.

\section{Uji Hipotesis Kelima}

Untuk menguji hipotesis kelima secara parsial langkah yang perlu dilakukan adalah dengan membandingkan nilai thitung dengan ttable pada taraf nyata $5 \%$. Jika thitung $>$ ttable maka pengaruhnya signifikan. Untuk mendapatkan ttabel digunakan tabel distribusi t untuk tingkat signifikasi 5\% dengan Degrees of Freedom $(\mathrm{df})=\mathrm{n}-\mathrm{k}$ maka didapat $\mathrm{df}$ adalah (100-6)= 95 dengan demikian ttabel adalah sebesar 1,646. Maka adapun hasil pengeujian dari variabel empati (empathy) (X5) berpengaruh signifikan terhadap kepuasan masyarakat (Y) hal ini didasarkan pada perbandingan antara thitung 5,509 dan ttabel 1,646 dan mempunyai nilai probabilitas sebesar $p<0,05$ yaitu $0,000<$ 0,05 , berarti terdapat pengaruh antara variabel empati (empathy) (X5) dengan variabel terikat kepuasan masyarakat (Y). Besarnya pengaruh dari variabel empati (empathy) (X5) terhadap kepuasan masyarakat (Y) dapat diketahui dari Standardized Coefficients Beta 0,863 yang berarti empati (empathy) (X5) ini memberikan pengaruh terhadap kepuasan masyarakat (Y) sebesar 86,1\%.

\section{Uji hipotesis Keenam}

Selanjutnya untuk mengevaluasi dan menguji hipotesis secara simultan. Untuk melakukan uji $\mathrm{F}$ (simultan) ini digunakan untuk membuktikan apakah variabel bebas seperti variabel berwujud (tangible), kehandalan (reliability), ketanggapan (responsibility), jaminan (assurance) dan empati (empathy) berpengaruh signifikan secara simultan terhadap kepuasan masyarakat. Untuk menilai Uji $\mathrm{F}$ dengan membandingkan nilai fhitung dengan ftabel, sedangkan untuk melihat nilai fhitung melalui data ANOVA berikut ini:

Tabel 5.20

ANOVA(b)

\begin{tabular}{|ll|r|c|c|}
\hline Model & & Df & F & Sig. \\
\hline 1 & Regression & 5 & 7,156 &, 000 \\
& Residual & 95 & & \\
& Total & 100 & & \\
\hline
\end{tabular}

Hasil regresi pada tabel ANOVA(b) tersebut memperlihatkan bahwa Fhitung adalah 7,156 sedangkan nilai Ftable dengan tingkat signifikan 5\%. Sedangkan untuk menghitung uji $\mathrm{F}$ digunakan program SPSS.

Kemudian untuk mencari ftabel dapat dilakukan dengan menentukan nilai Fhitung dengan cara menentukan Derajat bebas bagi pembilang (numerator) adalah (k-1) sehingga didapat (6-1) $=5$, sedangkan derajat kebebasan bagi pembagi (denumerator) adalah (n-k) sehingga didapat $(100-6)=94$. Dengan demikian didapat Ftabel dengan numerator $=5$ dan denumurator 95 sebesar 2,311.

Berdasarkan hal tersebut diperoleh di dapat Fhitung $(7,156)>$ Ftabel $(2,311)$ yang berarti variabel bebas yang terdiri dari variabel berwujud (tangible), kehandalan (reliability), ketanggapan (responsibility), jaminan (assurance) dan empati (empathy) berpengaruh signifikan secara simultan 
terhadap kepuasan masyarakat pada Polres Hulu Sungai Tengah (HST) Kalimantan Selatan.Untuk regresi dengan lebih dari dua variabel bebas digunakan $R$ Square sebagai keofesien diterminan. Terlihat $R$ Square sebesar 0,790 disini berarti 79\% variasi kepuasan masyarakat (Y) bisa dijelaskan oleh variabel seperti berwujud (tangible), kehandalan (reliability), ketanggapan (responsibility), jaminan (assurance) dan empati (empathy), sedangkan sisanya dari $(100 \%-79 \%)=$ $21 \%$ dijelaskan oleh variabel lain yang tidak dianalisis pada penelitian ini.

\subsection{Pembahasan}

1. Variabel berwujud (tangible) berpengaruh signifikan terhadap kepuasan masyarakat pada Polres Hulu Sungai Tengah (HST) Kalimantan Selatan. Hasil pengujian hipotesis pertama diketahui bahwa variabel berwujud (tangible) berpengaruh signifikan terhadap kepuasan masyarakat pada Polres Hulu Sungai Tengah (HST) Kalimantan Selatan, berdasarkan hal tersebut hendaknya pihakpolres dapat lebih meningktkan kembali akan aspek pelayanan dari segi berwujud (tangible) agar kepuasan masyarakat dapat dicapai sesuai dengan harapan. Upaya yang dapat dilakukan adalah dengan cara memberikan tampilan petugas/aparatur dalam melayani masyarakat dengan baik, memberikan kenyamanan tempat melakukan pelayanan, memeberikan kemudahan dalam proses pelayanan dan akses masyarakat dalam permohonan pelayanan serta menambag dan memperbanyak penggunaan alat bantu dalam pelayanan agar pelayanan dapat dilakukan dengan cepat.

2. Variabel kehandalan (reliability) berpengaruh signifikan terhadap kepuasan masyarakat pada Polres Hulu Sungai Tengah (HST) Kalimantan Selatan. Hasil pengujian hipotesis kedua diketahui bahwa variabel kehandalan (reliability) berpengaruh signifikan terhadap kepuasan masyarakat pada Polres Hulu Sungai Tengah (HST) Kalimantan Selatan, berdasarkan hal tersebut hendaknya pihak polres dapat lebih meningkatkan kembali akan faktor keandalan agar harapan untuk mencapai kepuasan masyarakat dapat dicapai, adapun usaya yang dapat dilakukan adalah dengan cara meningkatkan dan selalu menanamkan kepada petugas pelayanan agar selalu cermat dalam melayani dan dapat melakukan pelayanan sesuai standar yang direncanakan, selalu berupaya meningkatkan kemampuan petugas/aparatur dalam menggunakan alat bantu dalam proses pelayanan serta selalu memberikan inovasi dan keahlian petugas dalam menggunakan alat bantu dalam proses pelayanan cepat dan tepat.

3. Variabel ketanggapan (responsibility) berpengaruh signifikan terhadap kepuasan masyarakat pada Polres Hulu Sungai Tengah (HST) Kalimantan Selatan. Hasil pengujian hipotesis ketiga diketahui bahwa variabel ketanggapan (responsibility) berpengaruh signifikan terhadap kepuasan masyarakat pada Polres Hulu Sungai Tengah (HST) Kalimantan Selatan, berdasarkan hal tersebut hendaknya pihak polres dapat lebih meningkatkan kembali akan faktor ketanggapan (responsibility) agar kepuasan masyarakat dapat dicapai, adapun upaya yang dapat dilakukan untuk mencapai hal tersebut, yaitu selalu menanamkan kepada pertugas untuk dapat selalu merespon setiap masyarakat yang ingin mendapatkan pelayanan dengan baik, menanmkan dan selalu mengarahkan kepada petugas melakukan pelayanan dengan cepat, tepat dan cermat dan juga pihak polres perlu juga menerima keluhan masyarakat, agar kelemahan-kelemahan sistem dan manajemen pelayanan dapat diketahui sehingga hal apa saja yang kurang dapat dibenahi dan ditingkatkan sesuai dengan harapan.

4. Variabel jaminan (assurance) berpengaruh signifikan secara parsial terhadap kepuasan masyarakat pada Polres Hulu Sungai Tengah (HST) Kalimantan Selatan. Hasil pengujian 
hipotesis keempat diketahui bahwa variabel jaminan (assurance) berpengaruh signifikan secara parsial terhadap kepuasan masyarakat pada Polres Hulu Sungai Tengah (HST) Kalimantan Selatan, berdasarkan hal tersebut hendaknya pihak polres dapat lebih meningkatkan kembali akan jaminan (assurance) agar kepuasan masyarakat dapat terpenuhi, adapun usaha yang dapat dilakukan guna meningkatkan aspek jaminan pelayana tersebut, sebagai berikut pihak polres khususnya pata petugas selalu memberikan jaminan tepat waktu dalam pelayanan yang diberikan sesuai dengan yang ditetapkan, pihak polres dan petugas juga selalu berusaha memberikan jaminan biaya dalam pelayanan sesuai dengan aturan yang telah ditetapkan, pihak polres dan para petugas ditanamkan untuk dapat memberikan jaminan legalitas dalam pelayanan sesuai dengan aturan yang ditetapkan serta memberikan jaminan kepastian biaya dalam pelayanan tanpa ada calo.

5. Variabel empati (empathy) berpengaruh signifikan terhadap kepuasan masyarakat pada Polres Hulu Sungai Tengah (HST) Kalimantan Selatan Hasil pengujian hipotesis kelima diketahui bahwa variabel empati (empathy) berpengaruh signifikan terhadap kepuasan masyarakat pada Polres Hulu Sungai Tengah (HST) Kalimantan Selatan, berdasarkan hal tersebut hendaknya pihak polres dapat lebih meningkatkan kembali akan empati (empathy) agar kepuasan masyarakat dapat terpenuhi, adapun usaha yang dapat dilakukan yaitu pihak polres hendaknya selalu berusaha mendahulukan kepentingan masyarakat dalam pelayanan, kemudian pihak petugas diwajikan selalu bersikap baik dalam melayani dengan sikap ramah, sopan dan santu dalam bersikap dalam memberikan pelayanan serta pihak polres dan petugas harus mampu melayani dengan tidak diskriminatif (membeda-bedakan) permohonan atas pelayanan yang diajukan oleh masyarakat.

6. Variabel berwujud, kehandalan, ketanggapan, jaminan dan empati berpengaruh signifikan secara simultan terhadap kepuasan masyarakat pada Polres Hulu Sungai Tengah (HST) Kalimantan Selatan Hasil pengujian hipotesis kelima diketahui bahwa variabel berwujud, kehandalan, ketanggapan, jaminan dan empati berpengaruh signifikan secara simultan terhadap kepuasan masyarakat pada Polres Hulu Sungai Tengah (HST) Kalimantan Selatan, berdasarkan hal tersebut hendaknya pihak polres dapat lebih meningkatkan kembali akan faktor berwujud, kehandalan, ketanggapan, jaminan dan empati yang dapat mempengaruhi kepuasan masyarakat tersebut, usaha yang dapat dilakukan adalah selalu berusaha dan berkomitmen untuk selalu mengevaluasi, menilai kinerja layanan selama ini, kemudian melihat hal apa saja yang kurang baik dari aktivitas pelayanan kemudian cari solusinya untuk bagimana meningkatkan aspek pelayanan tersebut, hal ini selalu dilakukan secara kontineu, knapa ini harus selalu diperhatiakn dan ditingkatkan karena pelayanan yang baik memungkinkan sebuah organisasi/instansi untuk memperkuat kesetiaan, pandangan dan meningkatkan rasa pecaya, karena itu pelayanan yang baik harus selalu menjadi penting dalam operasi organisasi guna memberikan kepuasan kepada masyarakat. Selain itu proses evaluasi kinerja dimana tujuan akhir yang hendak dicapai adalah menyediakan pelayanan yang lebih baik, lebih efisien, dan lebih efektif berbasis dari kebutuhan masyarakat. Pelayanan dinilai memuaskan bila pelayanan tersebut dapat memenuhi kebutuhan dan harapan pengguna layanan. Kepuasan masyarakat dapat juga dijadikan acuan bagi berhasil atau tidaknya pelaksanaan program yang 
dilaksanakan pada suatu lembaga layanan publik.

\section{PENUTUP}

\subsection{Kesimpulan}

1. Hasil pengujian hipotesis pertama diketahui bahwa variabel berwujud (tangible) berpengaruh signifikan terhadap kepuasan masyarakat pada Polres Hulu Sungai Tengah (HST) Kalimantan Selatan

2. Hasil pengujian hipotesis kedua diketahui bahwa variabel kehandalan (reliability) berpengaruh signifikan terhadap kepuasan masyarakat pada Polres Hulu Sungai Tengah (HST) Kalimantan Selatan

3. Hasil pengujian hipotesis ketiga diketahui bahwa variabel ketanggapan berpengaruh signifikan terhadap kepuasan masyarakat pada Polres Hulu Sungai Tengah (HST) Kalimantan Selatan

4. Hasil pengujian hipotesis keempat diketahui bahwa variabel jaminan berpengaruh signifikan secara parsial terhadap kepuasan masyarakat pada Polres Hulu Sungai Tengah (HST) Kalimantan Selatan.

5. Hasil pengujian hipotesis kelima diketahui bahwa variabel empati berpengaruh signifikan terhadap kepuasan masyarakat pada Polres Hulu Sungai Tengah (HST) Kalimantan Selatan.

6. Hasil pengujian hipotesis kelima diketahui bahwa variabel berwujud, kehandalan, ketanggapan, jaminan dan empati berpengaruh signifikan secara simultan terhadap kepuasan masyarakat pada Polres Hulu Sungai Tengah (HST) Kalimantan Selatan

\subsection{Saran}

1. Pihak polres dapat lebih meningktkan kembali akan aspek pelayanan dari segi berwujud cara memberikan tampilan petugas/aparatur dalam melayani masyarakat dengan baik, memberikan kenyamanan tempat melakukan pelayanan, kemudahan proses pelayanan dan akses masyarakat dalam permohonan pelayanan cepat.
2. Pihak polres dapat lebih meningkatkan kembali akan faktor keandalan dengan cara meningkatkan dan selalu menanamkan kepada petugas pelayanan agar selalu cermat dalam melayani dan dapat melakukan pelayanan sesuai standar yang direncanakan, selalu berupaya meningkatkan kemampuan petugas menggunakan alat bantu serta selalu memberikan inovasi dan keahlian petugas dalam menggunakan alat bantu dalam proses pelayanan cepat dan tepat.

3. Pihak polres dapat lebih meningkatkan kembali akan faktor ketanggapan melalui selalu menanamkan kepada pertugas untuk selalu merespon setiap masyarakat yang ingin mendapatkan pelayanan dengan baik, menanmkan dan selalu mengarahkan kepada petugas melakukan pelayanan dengan cepat, tepat dan cermat dan juga pihak polres perlu juga menerima keluhan masyarakat, agar kelemahan-kelemahan sistem dan manajemen pelayanan dapat diketahui sehingga hal apa saja yang kurang dapat dibenahi dan ditingkatkan sesuai dengan harapan.

4. Pihak polres dapat lebih meningkatkan kembali akan jaminan melalui memberikan jaminan tepat waktu, memberikan jaminan biaya dalam pelayanan sesuai dengan aturan, pihak polres dan para petugas ditanamkan untuk dapat memberikan jaminan legalitas dalam pelayanan sesuai dengan aturan yang ditetapkan serta memberikan jaminan kepastian biaya dalam pelayanan tanpa ada calo.

5. Pihak polres dapat lebih meningkatkan kembali akan empati agar kepuasan masyarakat dapat terpenuhi, dengan selalu berusaha mendahulukan kepentingan masyarakat dalam pelayanan, kemudian petugas diwajibkan selalu bersikap baik dalam melayani dengan sikap ramah, sopan dan santu dalam bersikap dalam memberikan pelayanan serta pihak polres dan petugas harus mampu melayani dengan tidak membedabedakan permohonan atas pelayanan yang diajukan oleh masyarakat. 
6. Pihak polres selalu berusaha dan berkomitmen mengevaluasi, menilai kinerja layanan selama ini agar lebih efisien, dan lebih efektif berbasis dari kebutuhan masyarakat.

\section{DAFTAR PUSTAKA}

Alma. Buchari, 2012, Quality Control and Service Management, Alfabeta, Bandung

Dwiyanto, 2013, Manajemen Pelayanan Publik, Books, Jakarta

Dewantara, 2011, Kebijakan Publik, Salemba Empat, Jakarta

Erwin, 2011, Ketenagakerjaan dan Keorganisasian, Rineka Cipta, Jakarta

Hardiansyah 2011, Kualitas Layanan Publik, Erlangga, Jakarta

Kashmir, 2015, Konsep Pelayanan dan Kepuasan Pelanggan, Gramedia, Jakarta

Keputusan Menteri Pemberdayaan Aparatur Negara Pemerintah Nomor 96 Tahun 2012 pelaksanaan terhadap Kepmen Nomor KEP25/M.PAN/2/2009 tanggal 24 pebruari 2009 terdapat 14 indikator pelayanan, Jakarta

Keputusan Menteri PAN Nomor 63/KEP/M.PAN/7/2003, Pelayanan Terpadu Satu Atap, Jakarta

Lupiyoadi, 2012, Manajemen Pemasaran Jasa, PT. Remaja Rosdakarya. Bandung

Muchtarman, Muchtar, 2012, Pelayanan Publik Yang Profesional, Liberty,Jakarta

Moenir, 2012, Manajemen Pelayanan Publik, Bumi Aksara, Jakarta

Murhani Abdullah, 2011, Analisis Kualitas Pelayanan Terhadap Kepuasan Masyarakat Pada Kecamatan Kusan Hilir Kabupaten Tanah Bumbu, Unlam, Banjarmasin

Mucktar, 2010, Landasan Kerja Berdasarkan SOP, Intan Pariwara, Jakarta

Pratisto, 2004, Metode Penelitian, Bumi Aksara, Jakarta

Peraturan Menteri No. 96 Tahun 2012, pelayanan publik yang profesional, Jakarta
Permen No. 16 Tahun 2014, menjelaskan rancangan Standar Pelayanan Publik, Jakarta

Peraturan Menteri Aparatur Negara Dan Reformasi Birokrasi Republik Indonesia No. 14 Tahun 2017, tentang pelayanan, Jakarta

Rasyid, 2012, Mutu dan Pelayanan, Pro Teknologi, Bandung

Sumari, 2011, Manajemen Publik dan Kebijakan Publik, Rineka Cipta, Jakarta

Sugiarto, 2012, Perilaku dan Korganisasian, Rineka Cipta, Jakarta

Singarimbun. Masri, Effedny, 2005, Metode Penelitian Survey. PPSK.UGM. Yogyakarta

Susilo W, 2014, Pengaruh Pelayanan Terhadap Kepuasan Masyarakat pada Polsek Banjarmasin Timur Kota Banjarmasin, STIE Indonesia, Banjarmasin

Syamsir Alam, 2014, Pengaruh Kualitas Pelayanan Terhadap Kepuasan Masyarakat Pada Kantor Keluaran Pengambangan Kota Banjarmasin, Unlam Banjarmasin

SK Menpan No. KEP/ 25/ M.PAN /2/2004, tentang Pelayanan, Jakarta

Siregar, 2013, Mutu Pelayanan Publik, PT. Rajawali Press, Jakarta

Tjiptono, 2011, Manajemen Pelayanan Publik, Global Media, Jakarta

Undang-Undang Nomor 25 Tahun 2009 bab IV pasal 23, menjelaskan rancangan Standar Pelayanan, Jakarta

Undang-undang Nomor 32 Tahun 2004, tentang Pemerintahan Daerah, Jakarta

Undang-undang No 2 Tahun 2002, menjelaskan tugas pokok Kepolisian Negara Republik Indonesia, Jakarta

Undang-undang Kepegawaian Nomor 43 Tahun 1999, Pegawai Negeri Sipil (PNS), Jakarta

Umar, Ghozali, 2001, Metode Peneitian dan Riset dengan Aplikasi SPSS, Rajawali Press, Jakarta 